\title{
Advances in chemistry of chromone aminomethyl derivatives
}

\author{
Galyna P. Mrug, Mykhaylo S. Frasinyuk* \\ Department of chemistry of bioactive nitrogen containing heterocyclic bases, \\ Institute of Bioorganic and Petrochemistry NAS of Ukraine, \\ Murmanska Street, 1, Kyiv 02660, Ukraine \\ mykhaylo.frasinyuk@ukr.net
}

Keywords: chromone, Mannich base, electrophilic substitution, reductive amination, cycloaddition.

Chromones play an important role in the design and discovery of new pharmacologically active compounds. A large volume of reports dedicated to synthesis and study of properties of nitrogencontaining chromone derivatives show important role of chromone alkaloid-like compounds. The present review covers achievements in the field of synthesis of chromone aminomethyl derivatives as one of perspective scaffolds.

\section{Introduction}

The chemistry of aminomethyl derivatives and related Mannich bases has caused considerable interest throughout the last century. A few reviews and monographies are covering achievements in this field till 1994 [1-3]. The value of Mannich bases, both for synthetic organic chemistry and for pharmaceutics, is emphasized in these publications. It should be noted that one third of all published works on Mannich bases concerns their biological activity, in particular, antineoplastic, anesthetic, antibiotic properties. Additionally, important areas of their application include manufacturing of polymers, paints, surfactants, additives to lubricants, textiles, paper, etc [2-4].

The use of aminomethyl derivatives of chromones as one of the privileged scaffold in drug discovery [5] makes them perspective compounds for introduction of new pharmacophore substituents onto the chromone cycle and(or) construction of new oxygencontaining heterocyclic systems. Despite the fact that many reports are dedicated to synthesis and study of properties of aminomethyl chromone derivatives, the improvement of their synthesis methods and the research of properties are challenging problems at the moment.

\section{Results and discussion}

There is no clear distinction between aminomethyl derivatives and Mannich bases of aromatic and heterocyclic compounds. Usually, Mannich reaction is a three-component condensation between a XH substrate, an aldehyde and an amine. In main cases reactivity of (het)aromatic substrates for electrophilic 
substitution requires the presence of electrondonative hydroxy group(s). However, $\pi$-donative heterocycles could be aminomethylated in Mannich reaction without hydroxyl group activation of substrate. From this point of view, we considered synthesis of chromone aminomethyl derivatives regardless synthetic approach for them, which are significantly different and defined by the structural features of initial benzopyrones.

\section{Mannich reaction of chromones}

Mannich and Betti three-component condensation reaction discovered at early $1900 \mathrm{~s}$ using slightly modified reagents (aldehydes instead of formaldehyde and primary amines instead of secondary amines) and different mechanisms of reaction is the most effective for the synthesis of chromone aminomethyl derivatives. At present time, various aminomethyl derivatives have been synthesized using this reaction through all positions. The main limitation of Mannich-Betti reaction application is presence and location of phenolic group(s).

\subsection{Aminomethylation of 3-hydroxychromones}

Only one attempt is known for chromone aminomethylation in position 2 (Scheme 1) [6].

The reaction is possible exclusively in the presence of an hydroxyl group in position 3 activating electrophilic substitution to position 2 of chromone cycle, which usually undergoes attack of nucleophiles.

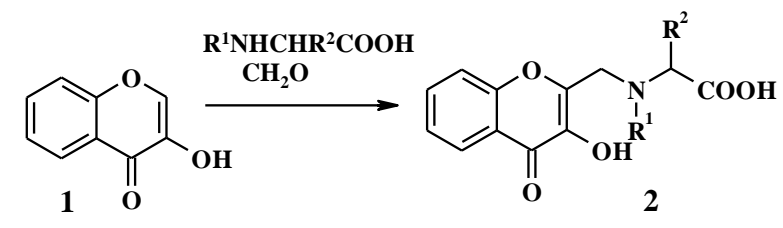

$\mathrm{R}^{1}=\mathrm{H}, \mathrm{Me} ; \mathrm{R}^{2}=\mathrm{H}, i-\mathrm{Pr}$

Scheme 1. Synthesis 2-aminomethylchromones by Mannich reaction.

\subsection{Synthesis of 3-aminomethylchromone derivatives}

As in the case of substitution of $\alpha$ hydrogen atom for dialkylaminomethyl group in acetophenones, 3-aminomethyl chromone derivatives $\mathbf{4}$ and $\mathbf{5}$ are obtained in conditions of Mannich reaction [7-12] (Scheme 2).

This reaction proceeds especially easily in the case of 2-dialkylaminochromone derivatives, and this is explained by additional electron donative effect of the amine group [1319]. It should be noted that it is one of the few examples of activation of Mannich reaction process by amine group. In addition, the synthesis of 3-aminomethyl derivatives from 2acetylaminochromones is reported also [20-22].

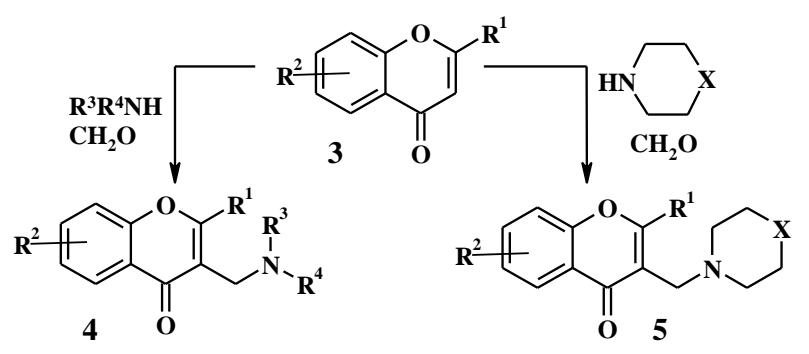

$\mathrm{R}^{1}=\mathrm{H}, \mathrm{Me}, \mathrm{Ar}, \mathrm{NHCOOMe}, \mathrm{N}(\mathrm{Alk})_{2} ; \mathrm{R}^{2}=\mathrm{H}, \mathrm{Cl}$, Alk, OAlk; $\mathrm{R}^{3}, \mathrm{R}^{4}=\mathrm{Alk}, \mathrm{X}=\mathrm{CH}_{2}, \mathrm{O}$, NMe

Scheme 2. Synthesis of 3-aminomethyl chromones by Mannich reaction. 
As reported, the deformylation of substrate, and followed by aminomethylation in position 3 of chromone was observed in the case of reaction of 3-formylchromones with sarcosine and formaldehyde [23].

\subsection{Aminomethylation of 5-hydroxychromones}

Reaction of 5-hydroxyflavone (6) with dimethylamine and formaldehyde in pyridine at $115^{\circ} \mathrm{C}$ produces mixtures of 8-, 6monodimethylaminomethyl- and 6,8-bisdimethylaminomethyl chromones 7-9, which were separated by chromatography (Scheme 3) [24].
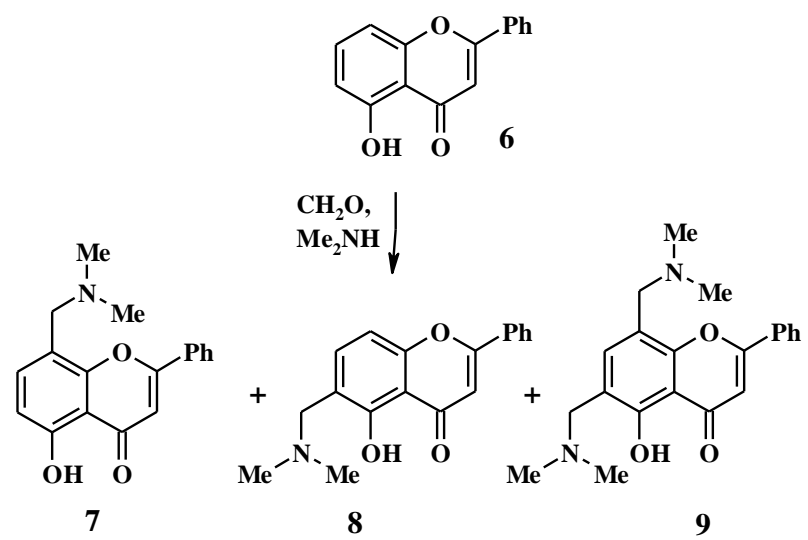

Scheme 3. Aminomethylation of 5-hydroxyflavones.

In the case of 5-hydroxyfurochromone derivatives 10, aminomethylation proceeds in position 9 of the furochromone cycle $[25,26]$ (Scheme 4).

It is absolutely expected since the position 6 of the chromone core is occupied. In this case, the reaction was carried out in glacial acetic acid, and amines were used as hydrochlorides. It should be mentioned that it is the almost unique example of acid catalyzed synthesis of aminomethyl chromone derivatives.

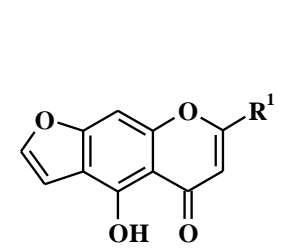

10

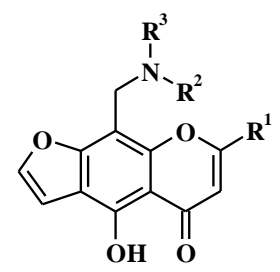

11
$\mathrm{R}^{1}=\mathrm{Me}, \mathrm{Ph}, \mathrm{C}_{6} \mathrm{H}_{4} \mathrm{Cl}-p, \mathrm{Py}-3 ; \mathrm{R}^{2}=\mathrm{R}^{3}=\mathrm{Et}, \mathrm{R}^{2} \mathrm{R}^{3}=\left(\mathrm{CH}_{2}\right)_{5}$, $\left(\mathrm{CH}_{2} \mathrm{CH}_{2}\right)_{2} \mathrm{O},\left(\mathrm{CH}_{2} \mathrm{CH}_{2}\right)_{2} \mathrm{NMe}$

Scheme 4. Aminomethylation of furochromones.

\subsection{Aminomethylation of 7-hydroxychromones}

The synthesis of 7-hydroxychromone Mannich bases is the most extensively studied. A number of 8-aminomethyl chromone derivatives 13-18 including amino acid derivatives were obtained in Mannich reaction with the use of formaldehyde and amines [11, 27-30].

The application of aminals as aminomethylating reagents proved to regioselectively aminomethylate chromones with electron donative [31-36] as well as electron withdrawing [37-43] heterocyclic or aromatic substituents (Scheme 5).

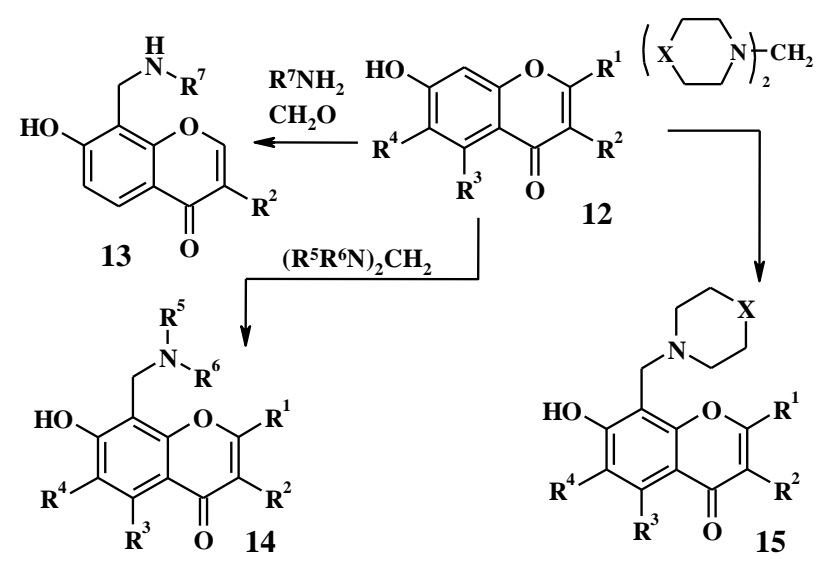

$\mathrm{R}^{1}=\mathrm{H}, \mathrm{Me}, \mathrm{CF}_{3}, \mathrm{Ar}, \mathrm{COOEt}, \mathrm{CHMe}_{2} ; \mathrm{R}^{2}=\mathrm{H}, \mathrm{Me}, \mathrm{Ar}$, 2-azahetaryl, 3-isoxazolyl; $\mathrm{R}^{3}=\mathrm{H}, \mathrm{Me} ; \mathrm{R}^{4}, \mathrm{R}^{5}, \mathrm{R}^{6}, \mathrm{R}^{7}=$ $\mathrm{H}, \mathrm{Alk} ; \mathrm{X}=$ bond, $\mathrm{O}, \mathrm{CH}_{2},\left(\mathrm{CH}_{2}\right)_{2}, \mathrm{CHMe}, \mathrm{NAlk}$, $\mathrm{NR}^{5} \mathrm{R}^{6}=12$-cytisin-12-yl;

Scheme 5. Aminomethylation of 7-hydroxychromones. 
The interaction 7-hydroxychromones 12 with amino acids and formaldehyde has some features. For instance, interaction of 7-hydroxy3-phenoxyisoflavones with amino acids and formaldehyde in aqueous-alcoholic medium results in the formation of various $\mathrm{N}$-substituted amino acid derivatives. In some cases, the formation bypass 8-ethoxymethyl derivatives was observed [28]. Aminomethylation of 7hydroxy-3-hetarylisoflavones led to the formation of 8-aminomethyl-7hydroxychromones 18 or 9carboxymethylchromenoxazines 17 , depending of the structure of amino acids or their derivatives [44] (Scheme 6).

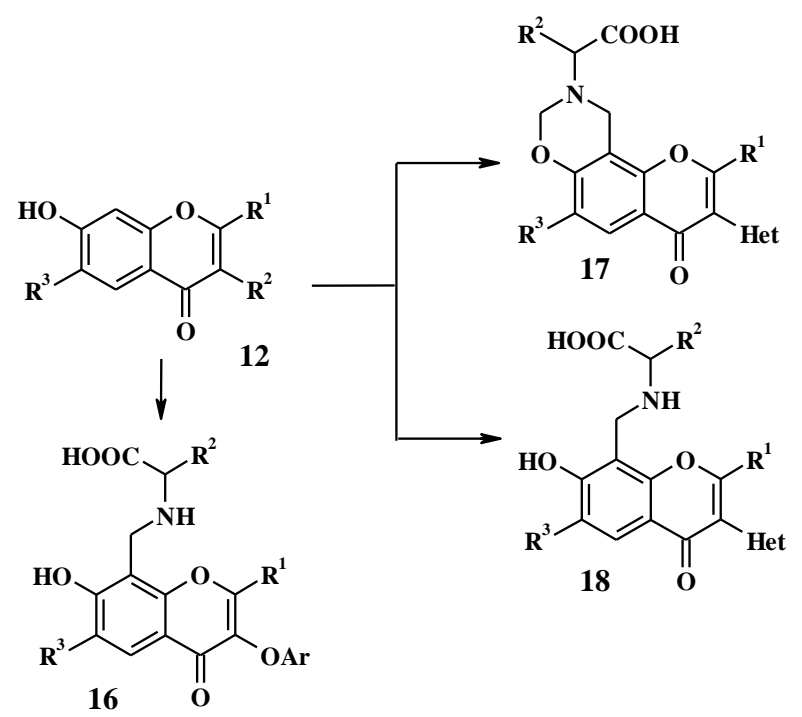

$\mathrm{R}^{1}=\mathrm{H}, \mathrm{CF}_{3}$;

$\mathrm{R}^{2}=\mathrm{H}, \mathrm{Me}, \mathrm{CHMe}_{2}, \mathrm{CH}_{2} \mathrm{CHMe}_{2}, \mathrm{CH}(\mathrm{Me}) \mathrm{Et} ; \mathrm{CH}_{2} \mathrm{Ph}$; $\mathrm{CH}_{2} \mathrm{COOBu}-t, \mathrm{CH}_{2}\left(\mathrm{CH}_{2}\right)_{3} \mathrm{NHCOOBu}-t$; $\mathrm{R}^{3}=\mathrm{Me}, \mathrm{Et}, \mathrm{Pr}$

Scheme 6. Aminomethylation of 7-hydroxychromones applying amino acid derivatives.

In the case of 5,7-dihydroxychromones 19 the aminomethylation often proceeds with formation of 6,8-bis-aminomethyl derivatives
20, 21, especially when using excess of aminomethylating agent [45-47] (Scheme 7).

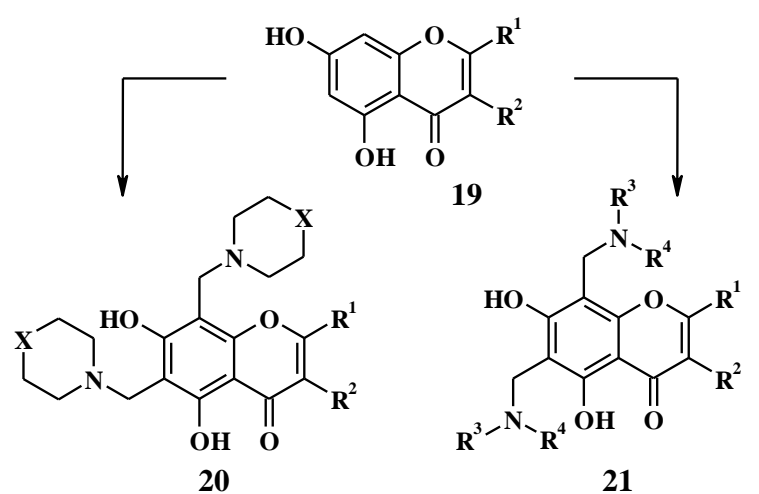

$\mathrm{R}^{1}=\mathrm{Me}, \mathrm{Ph} ; \mathrm{R}^{2}=\mathrm{H}, \mathrm{Ph}, \mathrm{C}_{6} \mathrm{H}_{5} \mathrm{OMe}-p ; \mathrm{R}^{3}, \mathrm{R}^{4}=\mathrm{Me}, \mathrm{Et} ;$ $\mathrm{X}=\mathrm{O}, \mathrm{CH}_{2}, \mathrm{CHMe}, \mathrm{NMe}, \mathrm{NCH}_{2} \mathrm{CH}_{2} \mathrm{OH}$

Scheme 7. General route for aminomethylation of 5,7dihydroxychromones.

The investigation of aminomethylation reaction with different ratio between substrate and amine-aldehyde has not allowed to find the conditions for a regioselective alkylation. Thus, aminomethylation of 5,7-dihydroxychromones 19 gave mixtures of 6- and 8-aminomethyl derivatives. 6-Aminomethyl derivatives were major products in some cases [48-51], but sometimes the formation of 8 substituted regioisomers was observed $[52,53]$.

Synthesis of Mannich bases of polyhydroxylated flavones $\mathbf{2 2}$ such as scutellarein (5,6,7,4'-tetrahydroxyflavone) [54], oroxylin A (5,7-dihydroxy-6-methoxyflavone) [55] and baicalein (5,6,7-trihydroxyflavone) [5658] was carried out involving secondary amines and formaldehyde. Electrophilic substitution proceeds with formation of 8-aminomethyl flavone derivatives 23 (Scheme 8). The aminomethylation reaction of irisolidone $(5,7-$ 
dihydroxy-6,4'-dimethoxyisoflavone) using methylamine proceeds in a similar way [59].<smiles>O=c1cc([AlH2])oc2cc(O)c(O)c(O)c12</smiles>

22<smiles>[Y][Y]([H])([H])Cc1c(O)c(O)c(O)c2c(=O)cc([Tl])oc12</smiles>

23
$\mathrm{R}^{1}=\mathrm{Ph}, \mathrm{C}_{6} \mathrm{H}_{4} \mathrm{OH}-p, \mathrm{C}_{6} \mathrm{H}_{4} \mathrm{OMe}-p ; \mathrm{R}^{2}=\mathrm{H}, \mathrm{Me}$;

$\mathrm{R}^{3}, \mathrm{R}^{4}=\mathrm{Alk}, \mathrm{Ph} ; \mathrm{R}^{3} \mathrm{R}^{4}=\left(\mathrm{CH}_{2}\right)_{4},\left(\mathrm{CH}_{2}\right)_{5},\left(\mathrm{CH}_{2} \mathrm{CH}_{2}\right)_{2} \mathrm{O}$, $\left(\mathrm{CH}_{2} \mathrm{CH}_{2}\right)_{2} \mathrm{NMe},\left(\mathrm{CH}_{2} \mathrm{CH}_{2}\right)_{2} \mathrm{NCOOBu}-t$

Scheme 8. Aminomethylation of naturally occurring polyhydroxylated flavones.

The use of primary amine with an excess of formaldehyde in the presence of $4-(\mathrm{N}, \mathrm{N}-$ dimethylamino)pyridine (DMAP) as catalyst in aminomethylation of 7-hydroxychromones $\mathbf{1 2}$ results in annelation of 1,3-benzoxazine cycle with formation of 9,10-dihydro- $4 \mathrm{H}, 8 \mathrm{H}$ chromeno[8,7-e][1,3] oxazin-4-one derivatives 24 [44, 60-63], and using of equimolar amount of aqueous formaldehyde formed 8-aminomethyl derivatives without annelation of 1,3benzoxazine cycle [30] (Scheme 9).
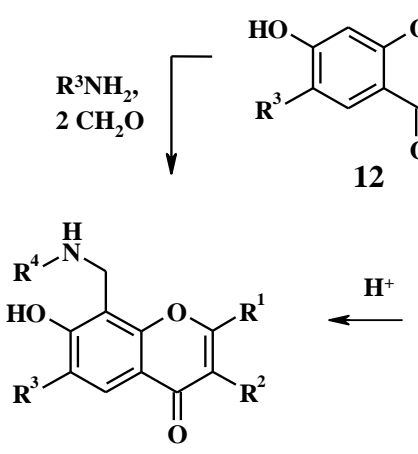

25

12<smiles></smiles><smiles>[Y]c1cc2c(=O)c([Y7])c([Y])oc2c2c1OCN([Y])C2</smiles>

24
$\mathrm{R}^{1}=\mathrm{H}, \mathrm{Me}, \mathrm{CF}_{3} ; \mathrm{R}^{2}=\mathrm{Ar} ; \mathrm{R}^{3}=\mathrm{H}, \mathrm{Alk} ;$ $\mathrm{R}^{4}=\mathrm{Alk}, \mathrm{CH}_{2} \mathrm{Ar}, \mathrm{CH}_{2} \mathrm{Het}, \mathrm{CH}_{2} \mathrm{Ar}, \mathrm{CH}_{2} \mathrm{CH}_{2} \mathrm{Het}$

Scheme 9. Aminomethylation of 7-hydroxychromones using primary amines.
As we reported, the application of $\omega$ aminoalcohols or their derivatives for aminomethylation of 7-hydroxychromones formed tautomeric mixture of 9- $(\omega-$ hydroxyalkyl)-9,10-dihydro-4H,8Hchromeno[8,7-e][1,3]oxazin-4-ones and 8-(3oxaheteryl)methyl-7-hydroxychromones. In some cases, presence of electron withdrawing 2$\mathrm{CF}_{3}$ group was a determinative factor for formation of 8-( $\omega$-hydroxyalkylaminomethyl)-7hydroxychromones [64].

The instability in acid medium of 3,4dihydro-1,3-benzoxazines was used for the development of simple preparative method for isoflavone Mannich bases synthesis with secondary amine residue. So, using aminomethylation of 7-hydroxyisoflavones with primary amines and excess of formaldehyde in the presence of DMAP, 1,3-oxazine ring was annelated to chromone core, which was cleaved by $\mathrm{HCl}$ with formation of 8-aminomethyl-7hydroxyisoflavone hydrochlorides 25 [61] (Scheme 9).

\subsection{Aminomethylation of 8-hydroxychromones}

As reported, aminomethylation of 8hydroxy-2,3-dimethylchromones $\mathbf{2 6}$ in classical Mannich reaction conditions takes place in position 7 [65]. In the case of 7-nitro derivative, the aminomethylation was observed in position 5 of chromone core [65] (Scheme 10). 


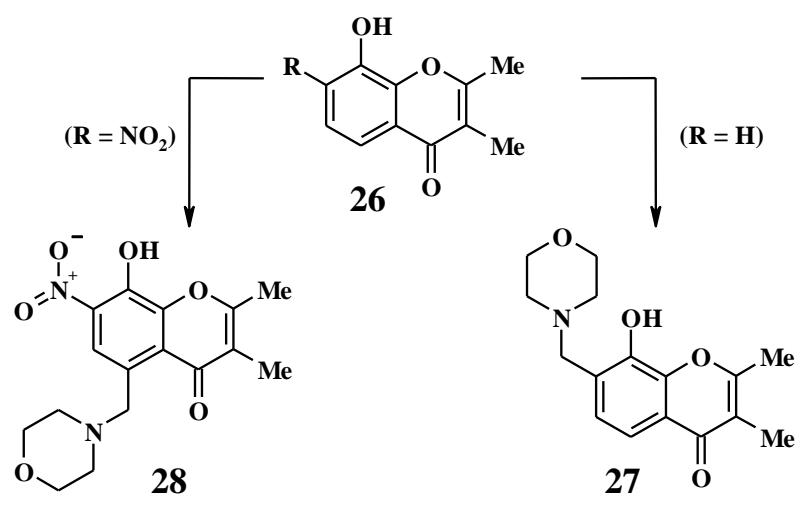

Scheme 10. Aminomethylation of 8-hydroxychromone derivatives.

\section{Exchange reactions of halogens and}

sulfonates

In addition to Mannich reaction, exchange reactions of halogens or sulfonates represent a convenient method for the synthesis of aminomethyl chromone derivatives. A series of 2-aminomethyl chromones $\mathbf{3 0}$ was obtained by substitution of halogen atom in 2-halogenomethylchromones $\mathbf{2 9}$ with primary or secondary amines [66-71]. The same reaction was carried out for the synthesis of 2-aminomethyl furochromone derivatives 31 [72, 73] (Scheme 11).

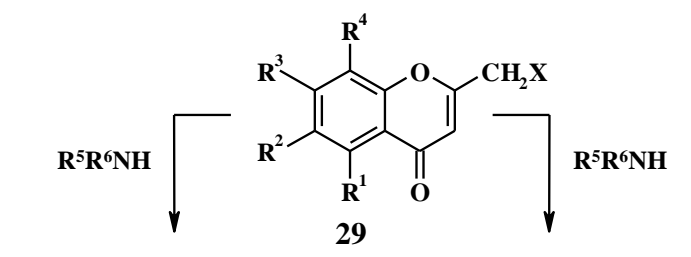<smiles>[Y]N([Y])Cc1cc(=O)c2c(OC)c3ccoc3c(OC)c2o1</smiles>

31<smiles>[Y][Y](=[V])Cc1cc(=O)c2c([Y7])c([Y])c([Y])c([Y])c2o1</smiles>

30
$\mathrm{X}=\mathrm{Cl}, \mathrm{Br}, \mathrm{I} ; \mathrm{R}^{1}=\mathrm{H}, \mathrm{OMe} ; \mathrm{R}^{2}=\mathrm{H}, \mathrm{OCH}_{2} \mathrm{Ar} ; \mathrm{R}^{3}=\mathrm{H}$, $\mathrm{OMe} ; \mathrm{R}^{4}=\mathrm{H}, \mathrm{OMe} ; \mathrm{R}^{5}, \mathrm{R}^{6}=\mathrm{Me}, \mathrm{Et}, \mathrm{CH}_{2} \mathrm{Ar}$;

$\mathrm{R}^{5} \mathrm{R}^{6}=\left(\mathrm{CH}_{2}\right)_{5},\left(\mathrm{CH}_{2} \mathrm{CH}_{2}\right)_{2} \mathrm{NAlk},\left(\mathrm{CH}_{2} \mathrm{CH}_{2}\right)_{2} \mathrm{NAr}$

Scheme 11. Synthesis of 2-aminomethylchromones by halogen substitution of halogens.
In addition, chlorine atom substitution with secondary alicyclic amines in dioxane allows to synthesize the 2-aminomethyl derivatives $\mathbf{3 3}$ from 2-chloromethyl-3-(4methylthiazol-2-yl)chromones 32 [74, 75] (Scheme 12).<smiles>[R]c1cc2c(=O)c(-c3nc(C)cs3)c(CCl)oc2cc1O</smiles>

$\mathrm{R}=\mathrm{Et}, n-\mathrm{Pr}$;

$\mathrm{X}=\mathrm{O}, \mathrm{CH}_{2}, \mathrm{CHCH}_{2} \mathrm{Ph}, \mathrm{NMe}, \mathrm{NAr}, \mathrm{NCH}_{2} \mathrm{Ar}$

Scheme 12. Synthesis of 2-aminomethyl-3hetarylchromones by substitution of halogens.

The alkylation of tryptamine derivatives or anilines with tosylates $\mathbf{3 2}$ led to the corresponding 2-aminomethyl chromones 33 and furochromones 34 [76, 77] (Scheme 13).<smiles>[Y10]CCc1c[nH]c2ccc(OC)cc12</smiles>

$\mathrm{R}^{1}=\mathrm{Me}, \mathrm{CH}_{2} \mathrm{Ar} ; \mathrm{R}^{2}=\mathrm{R}^{3}=\mathrm{H} ; \mathrm{R}^{2} \mathrm{R}^{3}=-\mathrm{CH}=\mathrm{CHO}-$

Scheme 13. Using of chromone tosylates for alkylation of amines

Substitution of halogens with amines was used for synthesis of aminomethyl chromone 
derivatives through different positions. Thus, 3 aminomethyl- [66, 78-80], 6-aminomethyl- [8184], 7-aminomethyl- [80, 84, 85] and 8aminomethylchromones [80, 84, 86-90] were obtained by this method. It should be noted that one of the first 7-methoxy-8-aminomethyl flavones were synthesized by this method [90].

The alkylation 2-aminoazaheterocycles with esters of 2-carboxy-3-chloromethyl chromones 35 with further cyclocondensation results in annelated derivatives of chromone $\mathbf{3 6}$, 37 [91, 92]. The same reaction with primary amines led to the formation of compound $\mathbf{3 8}$ (Scheme 14).

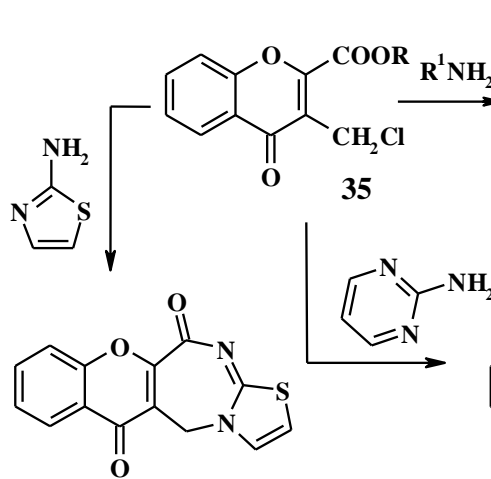

36<smiles>[Y]N1Cc2c(oc3ccccc3c2=O)C1=O</smiles>

38

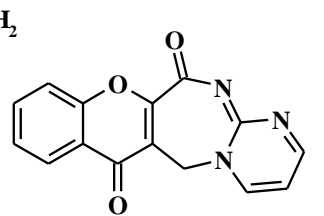

37

$\mathrm{R}=\mathrm{OH}, \mathrm{OMe}, \mathrm{OEt}, \mathrm{NH}_{2} ; \mathrm{R}^{1}=\mathrm{H}, \mathrm{Me}, \mathrm{Et}$

Scheme 14. Synthesis of fused heterocycles using 3chloromethyl-3-carboxychromones.

Substitution reaction of halogen essentially excludes the possibility of synthesis of chromone derivatives with hydroxy group(s), since the presence of free hydroxyl and halogenmethyl groups results in instability of such compounds. However, this reaction has a great practical value, as it makes possible the application of nitrogen-containing heterocyclic compounds which could not be involved in

Mannich reaction as amine component. For example, syntheses of aminomethyl chromone derivatives with imidazole [78-80], 1,2,3-triazole [91], 1,3,4-triazole [80] and tetrazolinone [93] residues were reported.

\section{Reactions of reductive amination}

One of the important methods for obtaining aminomethyl chromone derivatives is reductive amination involving formylchromones and primary or secondary amines. 2-[N(Arylmethyl)aminomethyl] chromones 40 were obtained by reductive amination using 2formylchromones 39, $\mathrm{NaBH}_{3} \mathrm{CN}$, and substituted benzylamines [94].<smiles>CCCCCOc1ccc2oc(C=O)cc(=O)c2c1OC</smiles>

38<smiles>[R]NCc1cc(=O)c2c(OC)c(O[13CH3])ccc2o1</smiles>

39
$\mathrm{R}=\mathrm{CH}_{2} \mathrm{C}_{6} \mathrm{H}_{4}-\mathrm{Cl}-p, \mathrm{CH}_{2} \mathrm{C}_{6} \mathrm{H}_{4}-\mathrm{Cl}-m, \mathrm{CH}_{2} \mathrm{C}_{6} \mathrm{H}_{4}-(\mathrm{CN})-m$

Scheme 15. Reductive amination of 2-formyl chromones.

3-Aminomethyl chromone derivatives were synthesized by reductive amination of 3formylchromone with $\mathrm{NaBH}(\mathrm{OAc})_{3}, \mathrm{NaBH}_{4}$ or $\mathrm{NaBH}_{3} \mathrm{CN}$ and amines [95-98]. Methanol or ethanol in the presence of acetic acid and $\mathrm{CH}_{2} \mathrm{Cl}_{2}$ were used as solvents.

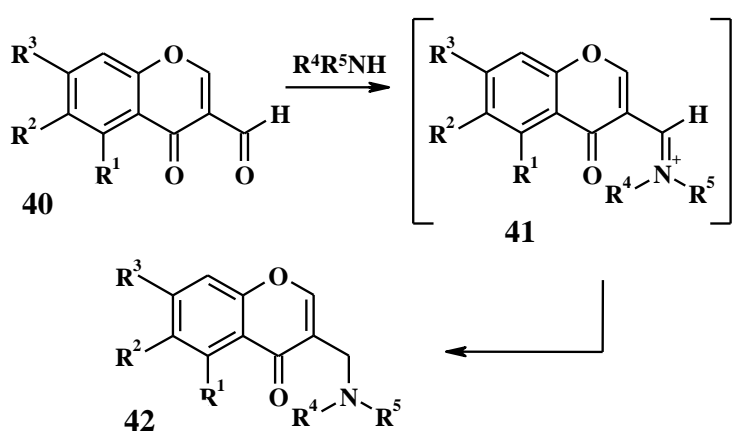


$\mathrm{R}^{1}=\mathrm{H}, \mathrm{OCH}_{2} \mathrm{C}_{6} \mathrm{H}_{11}$-cyclo;

$\mathrm{R}^{2}=\mathrm{R}^{3}=\mathrm{H} ; \mathrm{R}^{2} \mathrm{R}^{3}=-\mathrm{CH}=\mathrm{CH}-\mathrm{CH}=\mathrm{CH} ;$

$\mathrm{R}^{4}, \mathrm{R}^{5},=\mathrm{H}, \mathrm{Alk}, \mathrm{CH}_{2} \mathrm{Ar}$;

Scheme 16. Reductive amination of 3-formyl chromones.

Synthesis of 8-dialkylaminomethyl-7hydroxychromones $\mathbf{4 6}$ was developed via a multi-step procedure. Reductive amination of 8formylchromones $\mathbf{4 3}$ with primary amines and $\mathrm{NaBH}_{4}$ was successful after protection by acylation of 7-hydroxy group with $p$ methoxybenzoyl chloride (PMB-Cl). Nalkylation of 8-alkylaminomethylchromones $\mathbf{4 4}$ and various alkyls or benzyl chlorides, in the presence of DBU led to 7-O protected 8dialkylaminomethylchromones $\mathbf{4 5}[99,100]$

(Scheme 17).<smiles>CCCCOc1ccc2c(=O)cc(C)oc2c1C=O</smiles><smiles>[X]NCc1c(OCCC)ccc2c(=O)cc(C)oc12</smiles><smiles>[R]N([R])Cc1c(O)ccc2c(=O)cc(C)oc12</smiles>

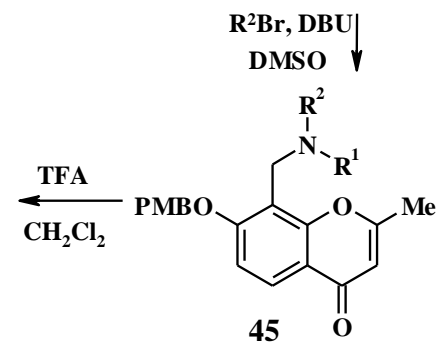

$\mathrm{R}^{1}, \mathrm{R}^{2}=\mathrm{Et}, \mathrm{Ar}, \mathrm{CH}_{2} \mathrm{Ar}$,

Scheme 17. Reductive amination of 7-O-protected 8formylchromones.

Deprotection of 7-hydroxy group was performed under action of trifluoroacetic acid.

\section{Reactions involving chromone Schiff's bases}

The chromane derivatives of amino phosphonic acids were synthesized in the process of addition of phosphorous acid derivatives to
Schiff's bases [101] (Scheme 18). The reaction conditions are very similar to classic KabachnikFields reaction.

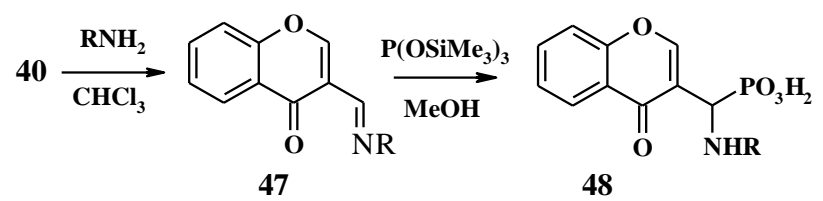

$\mathrm{R}=\mathrm{Bu}, \mathrm{CH}_{2} \mathrm{Ph}, \mathrm{C}_{6} \mathrm{H}_{4} \mathrm{Me}-p$

Scheme 18. Synthesis of chromen-3-ylaminomethylphosphonic acids.

The tetrahydro- $\beta$-carboline $\mathbf{5 0}$ was synthesized by Pictet-Spengler reaction of 3formylchromone $\mathbf{4 0}$ with tryptamine via cyclization of intermediate Schiff's base $\mathbf{4 9}$ [102].

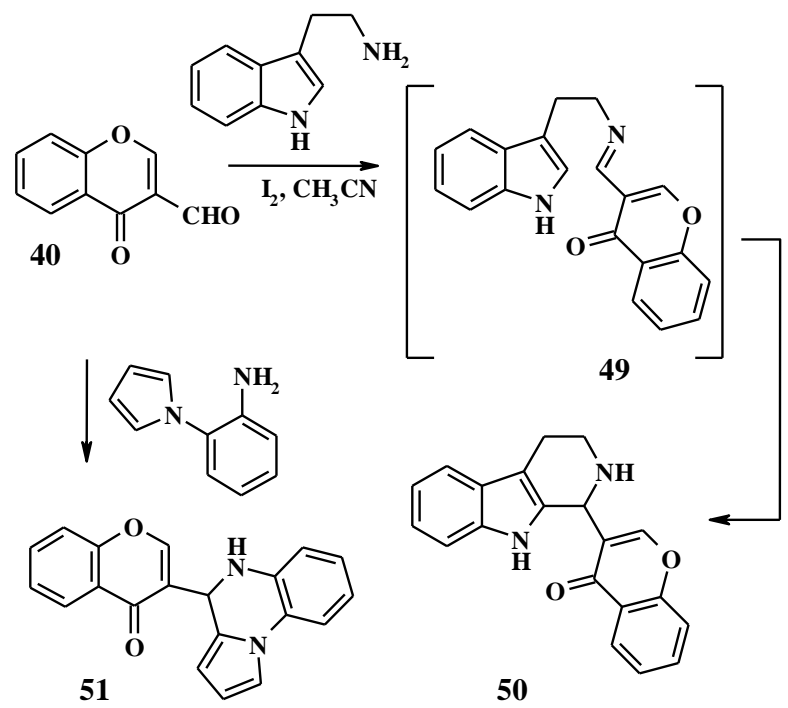

Scheme 19. Pictet-Spengler reaction of 3formylchromone.

A similar reaction employing 1-(2aminophenyl)pyrrole allowed to synthesize a pyrrolo[1,2-a]quinoxaline 51 [103] (Scheme 19).

The reaction of chromone-3-carboxaldehyde, aromatic amines and 1-vinylpyrrolidone- 2 in the presence of $\left(\mathrm{NH}_{4}\right)_{2} \mathrm{Ce}\left(\mathrm{NO}_{3}\right)_{6}$ 
led to tetrahydroquinolines $\mathbf{5 2}$, that can be oxidized to quinoline derivatives. The formation of compounds $\mathbf{5 2}$ is possible by oxidative cycloaddition of azomethines to activated double bond [104] (Scheme 20).

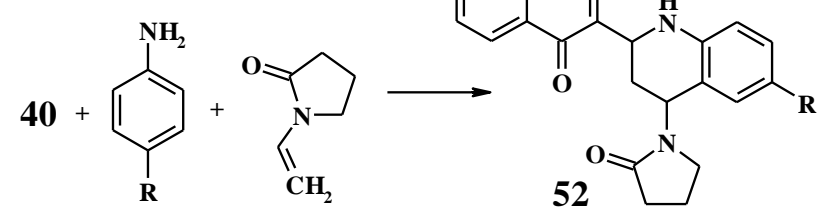

$\mathrm{R}=\mathrm{H}, \mathrm{Me}, \mathrm{OMe}$

Scheme 20. Oxidative cycloaddition of azomethines to 1vinylpyrrolidone-2.

Furthermore, the application of chromone carbaldehyde in Betti reaction, which mechanism is considered as addition of formed in situ azomethines to activated phenols, is known.

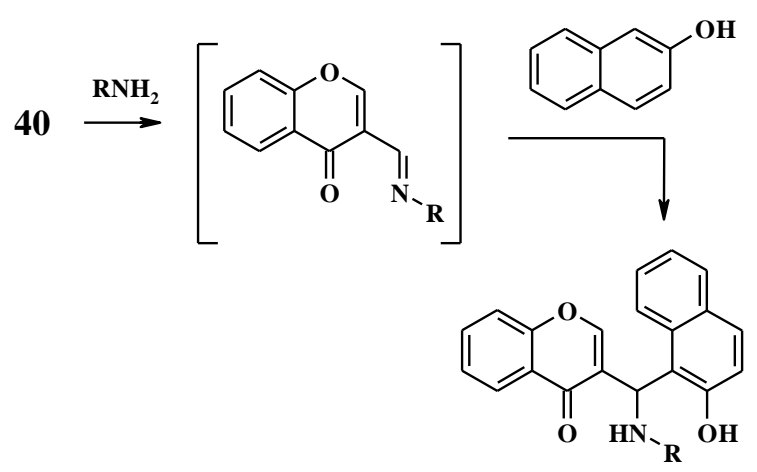

53

$\mathrm{R}=\mathrm{MeCO}, \mathrm{EtCO}_{2}$

Scheme 21. Using of 3-formylchromone in Betti reaction.

In the case of 3 -formylchromone, $\beta$ naphthol was used as $\mathrm{CH}$-substrate, and acetamide or ethyl carbamate were used as amine component [105] (Scheme 21). It was the first use of chromone-3-carboxaldehyde in a classical Betti reaction.
5. Synthesis of aminomethyl derivatives by cycloaddition reactions

The derivatives of 3-formylchromone are important synthons for the synthesis of aminomethyl derivatives by cycloaddition reactions. One of the important pathways for the synthesis of aminomethyl chromones is a construction of $\mathrm{sp}^{3}$ heterocyclic amine fragment based on secondary or tertiary amine residue. The transformation of the amine function, in particular its reduction, occurs in these reactions in most cases. However, a difference between structure of final compounds and classical products of reductive amination and involving Schiff's bases requires more detailed consideration.

As was shown above, interaction of 3formylchromones $\mathbf{4 0}$ with amino acids can proceed abnormally, in particular with their deformylation. The other outcome of the reaction between 3-formylchromones and sarcosine is the formation of chromone ylides 54. Different derivatives were synthesized by subsequent addition of dipolarophiles to this intermediate.

Heating of 40 with sarcosine and $\mathrm{N}$ phenyl maleimide in boiling toluene yield compounds 55 as result of stereospecific [3+2] cycloaddition. In some cases, starting 3-formylchromones were employed as dipolarophiles in this reaction with formation of compounds $\mathbf{5 6}$, and then to 57 after deformylation [106, 107]. The cycloaddition of $\mathrm{C}_{60}$ fullerene to ylide $\mathbf{5 4}$ formed 58 [108] (Scheme 22). 


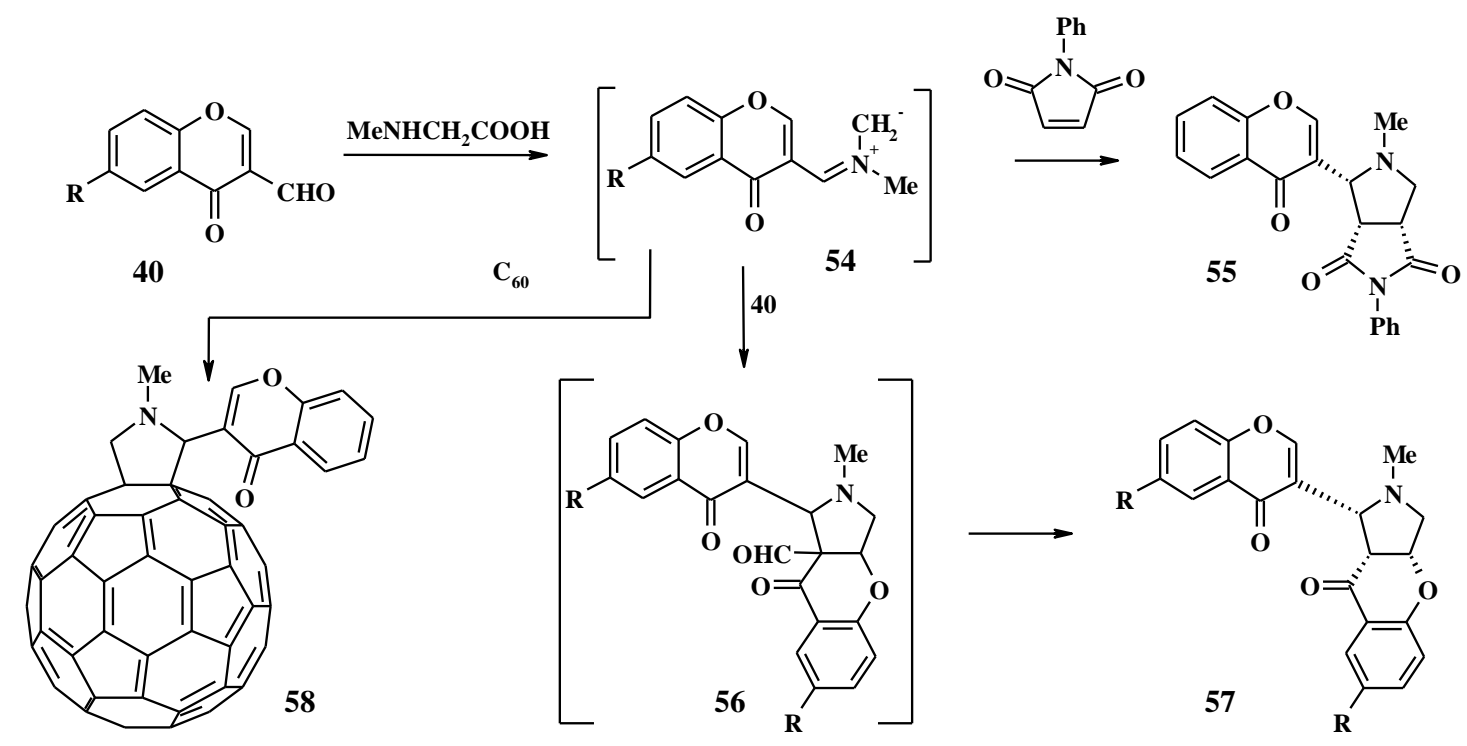

$\mathrm{R}=\mathrm{H}, \mathrm{Me}, \mathrm{Cl}$

Scheme 22. Applying of 3-formylchromone-sarcosine ylide for [3+2] cycloaddition reactions.

It is known that interaction of $2-(\mathrm{N}-$ reaction). In the case of reaction of $\mathbf{5 9}$ with alkenyl-N-aryl)-amino-3-formylchromones $\mathbf{5 9}$ sarcosine, methylene iminium zwitterion was with aromatic amines led to formation of Shiff's formed under decarboxylation of amino acid bases 60, which could undergo intramolecular fragment, which formed benzopyran[2,3[4+2]-cycloaddition in the presence of $\left.\mathrm{Ph}_{3} \mathrm{P} \quad b\right]$ pyrol[2,3- $d$ ]pyridines 63 in an intramolecular $\mathrm{HClO}_{4}$ with formation of [3+2]-cycloaddition [110] (Scheme 23). chromenonaphthyridines 61 [109] (Povarov

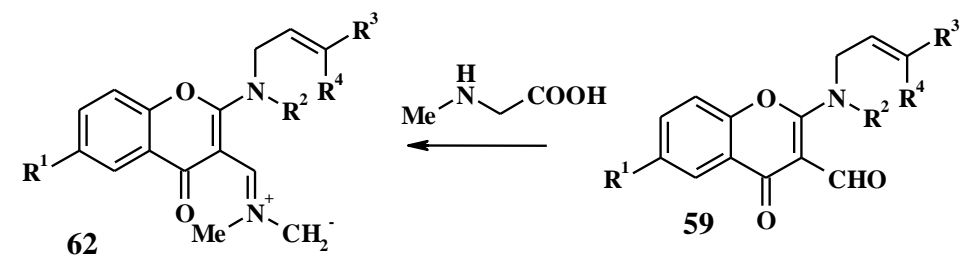<smiles>Nc1ccc(I)cc1</smiles>

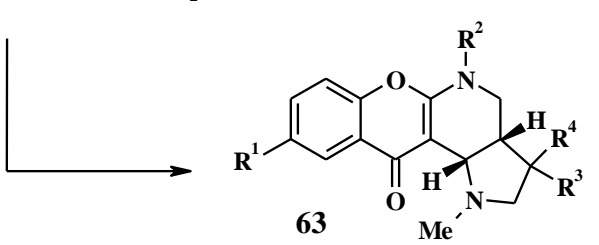

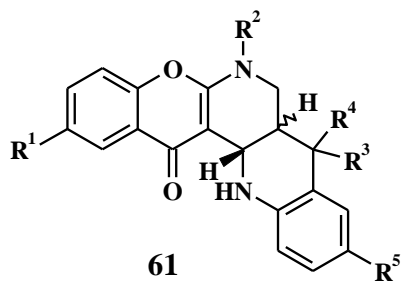<smiles>[Y]C([Y])=CCNc1oc2ccc([Y])cc2c(=O)c1/C=N/c1ccc([Y])cc1</smiles>

$\mathrm{R}^{1}, \mathrm{R}^{3}=\mathrm{H}, \mathrm{Me} ; \quad \mathrm{R}^{2}=\mathrm{Ph}, \mathrm{C}_{6} \mathrm{H}_{4} \mathrm{Me}-p ; \quad \mathrm{R}^{4}=\mathrm{H}, \mathrm{Me}, \mathrm{Ph} ;$

$\mathrm{R}^{5}=\mathrm{Me}, \mathrm{OMe}$

Scheme 23. [4+2] and [3+2] cycloaddition reaction based on 3-formyl-2-isoprenylaminochromone derivatives.

As reported, treatment of $\mathbf{5 9}$ with cyclization or rearrangement to form mixtures of hydroxylamine results in the synthesis of 64 and 65 [111] (Scheme 24). nitrones, which undergo intramolecular 
<smiles>[Y]C=CCNc1oc2ccc(C#[Y10][H])cc2c(=O)c1C(=O)N[Z17]</smiles><smiles>[Y]C1ON([Y2])C2c3c(oc4ccccc4c3=O)N(c3ccccc3)CC12</smiles>

$\mathrm{R}^{1}=\mathrm{H}, \mathrm{Me}, \mathrm{Ph} ; \quad \mathrm{R}^{2}=\mathrm{Me}, \mathrm{Ph}$

Scheme 24. Rearrangement and cyclization reaction of nitrones from 3-formyl-2-isoprenylaminochromones.

The same cycloaddition reaction was investigated for 8-formyl-7-isoprenyloxychromones. Reaction of 7-isoprenyloxy-8formylchromones $\mathbf{6 6}$ with $\mathrm{N}$-substituted hydroxylamine in the presence of PEG-400 led to formation of nitrones $\mathbf{6 7}$ that undergo 1,3intramolecular cyclization to chromenopyrano[4,3-c]isoxazoles 68. The reaction is stereoselective and proceeds exclusively with the formation of cis-annelated derivatives of chromanoisoxazole [112]. The derivatives of tetrahydrochromeno[4,3b]quinoline 69 were synthesized from 7isoprenyloxy-8-formylchromones $\mathbf{6 6}$ by intramolecular [4+2] Diels-Alder iminoreaction in the presence of $\mathrm{Yb}(\mathrm{OTf})_{3}$ from intermediate Shiff's bases [113].

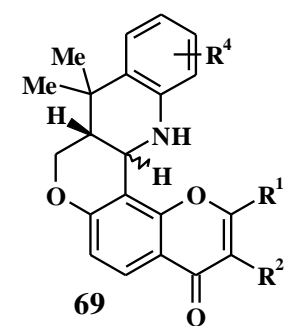

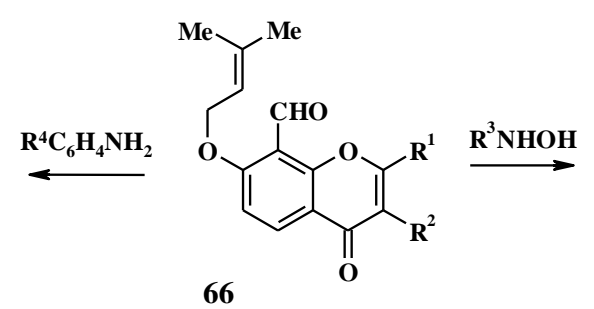<smiles>[R]c1oc2c(C=[N+]([Y])[O-])c(OCC=C(C)C)ccc2c(=O)c1[Y10]</smiles>

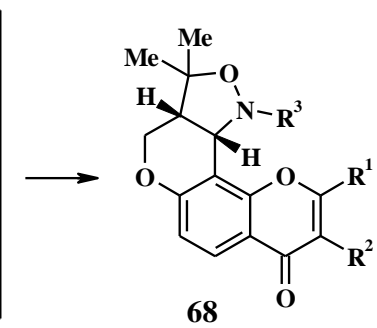

$\mathrm{R}^{1}=\mathrm{H}, \mathrm{Me} ; \mathrm{R}^{2}=\mathrm{Me}, \mathrm{Ph} ; \mathrm{R}^{3}=\mathrm{PhCH}_{2}, \mathrm{C}_{6} \mathrm{H}_{4} \mathrm{OMe}-p, \mathrm{C}_{6} \mathrm{H}_{4} \mathrm{Me}-p, \mathrm{C}_{6} \mathrm{H}_{11}-\mathrm{c} ; \mathrm{R}^{4}=\mathrm{H}, \mathrm{Me}, \mathrm{Br}, 1$-naphtyl

Scheme 25. [4+2] and [3+2] cycloaddition reaction based on 8-formyl-7-isoprenyloxychromone derivatives.

Proline derivative of chromone 71, 72 subsequent 1,3-cycloaddition of fumaric acid were synthesized by reaction of 3- derivatives. formylchromone $\mathbf{4 0}$ and DL-alanine with

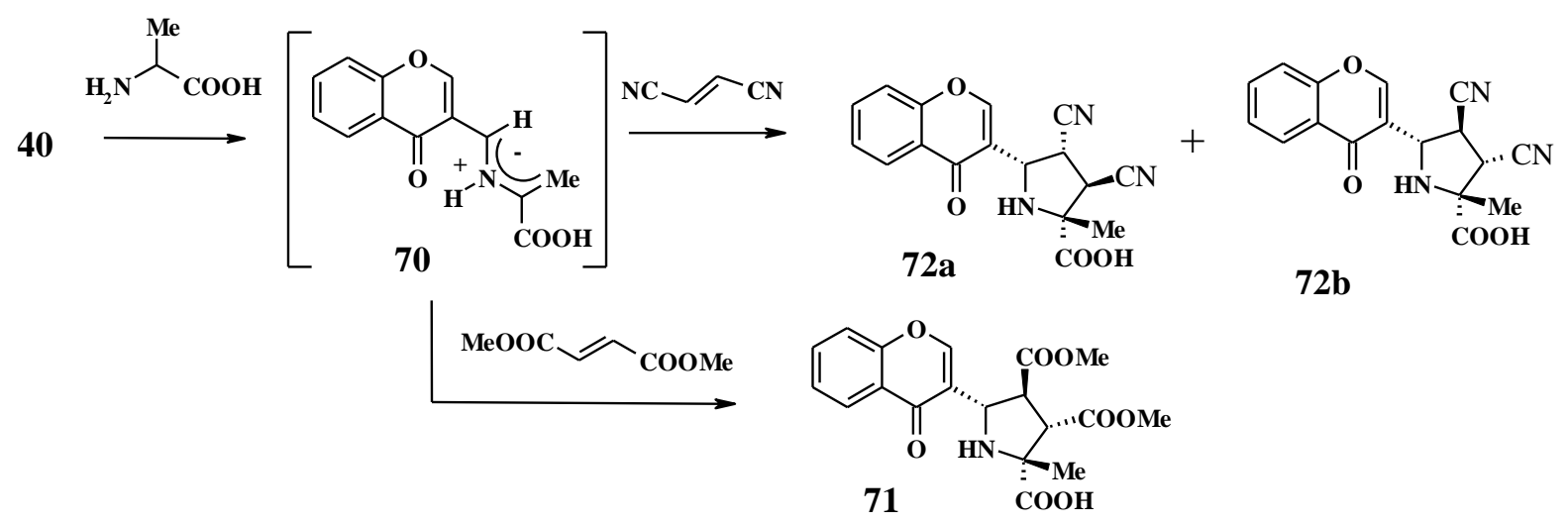

Scheme 26. Synthesis of proline derivatives from 3-formylchromones.

When using dimethyl fumarate, the stereospecific formation of $\mathbf{7 1}$ was observed. The 
use of fumaronitrile results in the formation of a isomeric mixture of dicyano adducts $\mathbf{7 2 a}$ and $\mathbf{7 2 b}$ [114] (Scheme 26).

1,3-Dipolar cycloaddition to nitrones $\mathbf{7 3}$ obtained from 3-formylchromones is also used for synthesis of isoxazolidine derivatives 74-77.

The isoxazolidine derivatives $\mathbf{7 4 ,} 75$ were synthesized under interaction of nitrones with acrylic acid derivatives $[115,116]$. The use of maleimide in [3+2] cycloaddition led to the formation of compounds 76, and 2,3dihydrofuran formed cyclic acetals 77 [116] (Scheme 27).<smiles>CC[C@@H]1C(C(C)C)ON(c2ccccc2)[C@H]1c1coc2ccccc2c1=O</smiles>

77<smiles>[R]c1cc2occ([C@H]3C[C@@H]4C(=O)N(c5ccccc5)C(=O)[C@@H]4ON3c3ccccc3)c(=O)c2cc1[Y2]</smiles><smiles>[R]c1cc2occ(/C=[N+](\[O-])c3ccccc3)c(=O)c2cc1[R]</smiles>
73<smiles>[R]C(=C)C1CCCC1</smiles><smiles></smiles>

74<smiles>O=C1C=CC(=O)N1c1ccccc1</smiles>

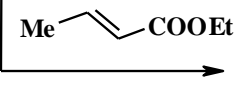<smiles>CCOC(=O)[C@H]1ON(c2ccccc2)[C@H](c2coc3ccccc3c2=O)C1C</smiles>

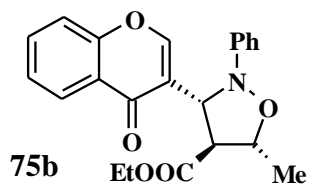

$\mathrm{R}^{1}=\mathrm{H}, \mathrm{Me}, \mathrm{F}, \mathrm{Cl}, \mathrm{Br} ; \mathrm{R}^{2}=\mathrm{H}, \mathrm{Cl} ; \mathrm{R}^{3}=\mathrm{OEt}, \mathrm{OBu}-i, \mathrm{CN}, \mathrm{Ph}, \mathrm{CO}_{2} \mathrm{Alk}, \mathrm{COMe}, \mathrm{COOMe}, \mathrm{CONH}_{2}, \mathrm{Py}-2 ; \mathrm{R}^{4}=\mathrm{H}, \mathrm{Me}$ Scheme 27. [3+2] cycloaddition reaction to 3 -formylchromone nitrones.

N-methyl- and N-benzyl-3-chromanyl nitrones $\mathbf{7 3}$ also form corresponding [3+2]cycloadducts with acetylenedicarboxylates. It should be noted that in the cycloaddition of dimethyl ether of acetylenedicarboxylic acid under activation with triphenylphosphine, the reaction cannot proceed through a [5+2]cycloaddition. It is the author's opinion, that the reaction in this case formally proceeds through the addition of an allene, which is formed in the interaction of acetylenedicarboxylic acid ester and triphenylphosphine [117] (Scheme 28). 


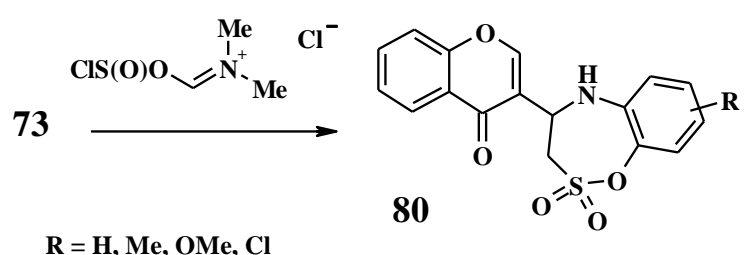

Scheme 29. Cycloaddition of sulfene to 3-formylchromone nitrones.

\section{Miscellaneous reactions}

The addition of $\mathrm{Cbz}-\mathrm{NH}_{2}$ to 3methylenechroman-4-ones 81 (Michael azareaction) with subsequent oxidation of 3aminomethyl flavanones $\mathbf{8 1}$ by action of $\mathrm{SeO}_{2}$ under microwave irradiation was suggested for the synthesis of 3-aminomethyl derivatives of halogen substituted flavones 82 [119] (Scheme 30).<smiles>C=C1C(=O)c2cc(Cl)cc(Br)c2OC1[13CH]=[W]</smiles>

81<smiles>CNCC1C(=O)c2cc(Cl)cc(Br)c2OC1[125I]</smiles>
82<smiles>[Li][Mg]</smiles>
MW $170^{\circ} \mathrm{C}$
Scheme 30. Synthesis of 3-aminomethyl chromones by Michael azareaction.

This method opens new opportunities for the introduction of primary aminomethyl group in position 3 of flavones.

Construction of the chromone ring bearing a aminomethyl function is the second general pathway for the synthesis of topic compounds.

The synthesis of 3-aminomethyl chromones 5 by reaction of 1-(2hydroxyphenyl)butanedione-1,3 with formaldehyde and secondary amines at room temperature in neutral medium was described. As the authors noted, the cyclization of this diketone into 2-methylchromone $\mathbf{3}$ without following Mannich reaction was only observed in acid environment [120] (Scheme 31).
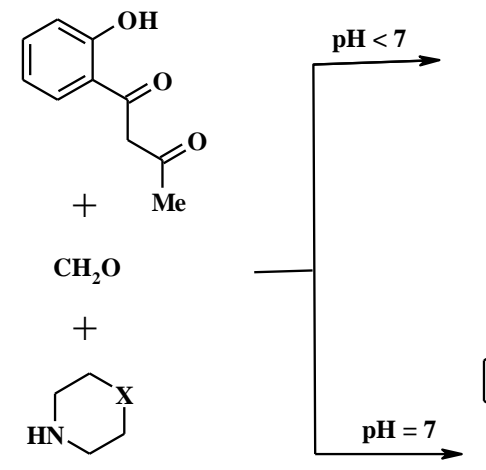<smiles>[M]c1cc(=O)c2ccccc2o1</smiles><smiles>[C+]1C=C2C=C12</smiles><smiles>Cc1oc2ccccc2c(=O)c1CN1CCCCC1</smiles>

$\mathrm{X}=$ bond, $\mathrm{CH}_{2}, \mathrm{O}, \mathrm{NAr}$

Scheme 31. Aminomethylation of 1-(2-hydroxyphenyl)butanedione-1,3.

As reported, the interaction of 2hydroxybenzoyl pyruvate and Schiff's bases, or aromatic aldehydes and aliphatic amines proceeds with the formation of derivatives of 1,2dihydrochromeno[2,3-c]pyrolo-3,9-diones [121-123].

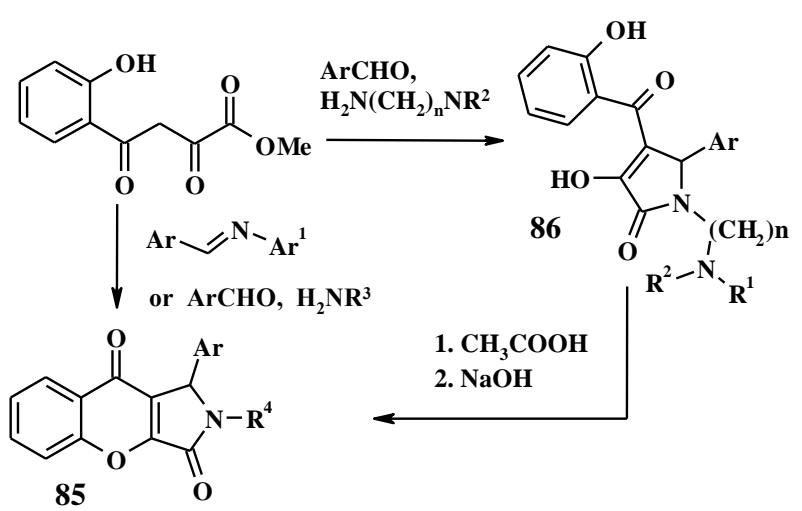

$\mathrm{R}^{1}, \mathrm{R}^{2}=$ Alk, $\mathrm{R}^{1} \mathrm{R}^{2}=\left(\mathrm{CH}_{2} \mathrm{CH}_{2}\right)_{2} \mathrm{O}, \mathrm{n}=2,3$

$\mathrm{R}^{3}=\mathrm{Alk} ; \mathrm{R}^{4}=\mathrm{Alk}, \mathrm{Ar}^{1},\left(\mathrm{CH}_{2}\right) \mathrm{nNR}^{1} \mathrm{R}^{2}$,

Scheme 32. Synthesis of dihydrochromeno[2,3-c]pyrolo3,9-diones from pyruvates. 
However, introduction of $\mathrm{N}^{\prime}, \mathrm{N}^{\prime}-$ substituted 1- $\omega$-diaminoalkanes in the reaction formed 5-aryl-4-acyl-3-hydroxy-1-alkyl-1,5dihydro-2H-pyrol-2-ones 86, which were transformed into the final derivatives $\mathbf{8 5}$ in boiling acetic acid (Scheme 32).

The synthesis of 2-aminomethyl derivatives $\mathbf{8 9}$ is reported through a Claisen condensation of 2-hydroxyacetophenone $\mathbf{8 8}$ with aminoacetic acid derivatives and $\mathrm{NaH}$ in dioxane. A number of 2-(1heteryl)methylchromones were synthesized by this method [124] (Scheme 33).<smiles>[Y4]N([R])CC(=O)OCC</smiles>

87

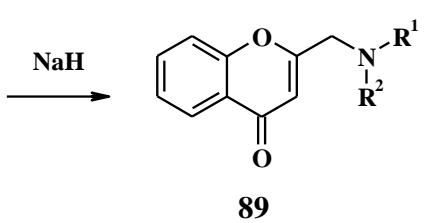

89
$\mathrm{R}^{1}, \mathrm{R}^{2}=\mathrm{Me}, \mathrm{Et}, \mathrm{Bu} ; \quad \mathrm{R}^{1} \mathrm{R}^{2}=\left(\mathrm{CH}_{2}\right)_{5},\left(\mathrm{CH}_{2} \mathrm{CH}_{2}\right)_{2} \mathrm{O}$, $\left(\mathrm{CH}_{2} \mathrm{CH}_{2}\right)_{2} \mathrm{NH},\left(\mathrm{CH}_{2} \mathrm{CH}_{2}\right)_{2} \mathrm{NMe}$

Scheme 33. Using Claisen condensation for the synthesis of 2-aminomethylchromones.<smiles>COc1cc(O)c(C(=O)/C=C/c2ccccc2Cl)c(OC)c1</smiles>

90 93<smiles>[Y]N([Y])Cc1c(OC)cc(O)c2c(=O)cc(-c3ccccc3Cl)oc12</smiles><smiles>[Y]N([Y])Cc1c(OC)cc(OC)c(C(=O)/C=C/c2ccccc2Cl)c1O</smiles>

$\mathrm{I}_{2}$, DMSO<smiles>[Y]N([Y])Cc1c(OC)cc(OC)c2c(=O)cc(-c3ccccc3Cl)oc12</smiles>

$\mathrm{R}^{1}, \mathrm{R}^{2}=\mathrm{Alk}, \mathrm{CH}_{2} \mathrm{COOH}, \quad \mathrm{R}^{1} \mathrm{R}^{2}=\left(\mathrm{CH}_{2}\right)_{4}, \quad\left(\mathrm{CH}_{2}\right)_{5}$, $\left(\mathrm{CH}_{2} \mathrm{CH}_{2}\right)_{2} \mathrm{O},\left(\mathrm{CH}_{2} \mathrm{CH}_{2}\right)_{2} \mathrm{NMe},\left(\mathrm{CH}_{2} \mathrm{CH}_{2}\right)_{2} \mathrm{~S}$

Scheme 34. Synthesis of flavopiridol isomers from chalcones.

In addition to the above-mentioned reactions, the cyclization of aminomethyl chalcones 91, obtained by Mannich reaction from chalcones 90, is also used for the synthesis of flavopipidol isomers 93. Demethylation of 5methoxygroup was carried out using $\mathrm{AlCl}_{3}$ in $\mathrm{CH}_{3} \mathrm{CN}$. The saponification of 7-methoxy group of compounds 92 is not observed [125] (Scheme 34).<smiles>O=Cc1c(O)cccc1[Tl]</smiles><smiles>[R]C1CC(N2CCOCC2)=CCN1[Y]</smiles><smiles>[Y2]c1ccc([Y2])c2c1O[C@]1(N3CCOCC3)CC([R])N([Y])C[C@H]2[C@H]1O</smiles>

95<smiles>O=c1c2ccccc2oc2ccncc12</smiles>

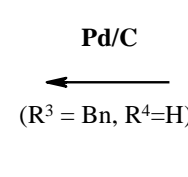

97<smiles>[R]c1ccc([R])c2c(=O)c3c(oc12)CC([R])N([R])C3</smiles>

96

$\mathrm{R}^{1}=\mathrm{H}, \mathrm{Me} ; \mathrm{R}^{2}=\mathrm{H}, \mathrm{Cl}, \mathrm{Br}, \mathrm{R}^{3}=\mathrm{Bn}, \mathrm{R}^{4}=\mathrm{H}, \mathrm{R}^{3} \mathrm{R}^{4}=\left(\mathrm{CH}_{2}\right)_{3}$

Scheme 35. Using Diels-Alder hetero-reaction for the synthesis tertiary amines.

Diels-Alder hetero-reaction using salicylaldehydes 94 and enamines is a remarkable method for the synthesis of fused chromone-based heterocyclic systems. Particularly, hydrogenated chromono[3,2$f$ ]indolizines $\left(\mathbf{9 5}, 96, \mathrm{R}^{3} \mathrm{R}^{4}=\mathrm{CH}_{2} \mathrm{CH}_{2} \mathrm{CH}_{2}\right)$ [126] and chromeno[3,2-c]pyridines $\left(\mathbf{9 5}, \mathbf{9 6}, \mathrm{R}^{3}=\mathrm{Bn}\right.$, $\left.\mathrm{R}^{4}=\mathrm{H}\right)$ [127] were synthesized by this method (Scheme 35).

\section{Conclusions}

In conclusion, the review combines the available literature on the preparation of 
chromone aminomethyl derivatives using several synthetic approaches. The literature is divided in chapters according to traditional organic chemistry synthetic methods. These informations are valuable when planning synthetic routes towards new possible chromone alkaloid-like compounds for biological studies and drug design.

\section{References}

[1] M. Tramontini, Synthesis, 1973, 1973, 12, 703.

[2] M. Tramontini, L. Angiolini, Tetrahedron, 1990, 46, 6, 1791.

[3] M. Tramontini, L. Angiolini, Mannich Bases: Chemistry and Uses. (CRC Press, Boca Raton, 1994).

[4] G. Roman, Eur. J. Med. Chem., 2015, 89, 743.

[5] R. S. Keri, S. Budagumpi, R. K. Pai, R. G. Balakrishna, Eur. J. Med. Chem., 2014, 78, 340.

[6] R. A. Irgashev, V. Y. Sosnovskikh, A. A. Sokovnina, G.-V. Röschenthaler, J. Heterocycl. Chem., 2010, 47, 4, 944.

[7] P. F. Wiley, J. Am. Chem. Soc., 1952, 74, 17, 4326.

[8] M.-C. Sacquet, M.-C. Fargeau-Bellassoued, B. Graffe, J. Heterocycl. Chem., 1991, 28, 3, 667.

[9] J. Bolós, T. Loscertales, J. Nieto, A. Sacristán, J. A. Ortiz, J. Heterocycl. Chem., 2000, 37, 5, 1203.

[10] F. Eiden, U. Rehse, Chem. Ber., 1974, 107, 3, 1057.

[11] A. Ermili, M. Mazzei, G. Roma, C. Cacciatore, Farmaco, 1977, 32, 5, 375.

[12] U. Rehse, Arch. Pharm., 1975, 308, 11, 881.

[13] M. Mazzei, E. Sottofattori, M. Di Braccio, A. Balbi, G. Leoncini, E. Buzzi, M. Maresca, Eur. J. Med. Chem., 1990, 25, 7, 617.

[14] M. Mazzei, E. Sottofattori, R. Dondero, M. Ibrahim, E. Melloni, M. Michetti, Farmaco, 1999, 54, 7, 452.
[15] A. Ermili, M. Mazzei, G. Roma, A. Ambrosini, N. Passerini, Farmaco, 1974, 29, 3, 237

[16] A. Ermili, M. Mazzei, G. Roma, Ambrosini, Passerini, Farmaco, 1975, 30, 12, 1001

[17] A. Balbi, A. Ermili, G. Roma, Farmaco, 1976, $31,9,627$

[18] G. Romussi, G. Ciarallo, Farmaco, 1977, 32, 9,635

[19] M. Mazzei, E. Nieddu, E. Melloni, R. Minafra, Farmaco, 2003, 58, 2, 121.

[20] V. A. Zagorevskii, S. M. Glozman, L. A. Zhmurenko, Chem. Heterocycl. Compd., 1970, 6, 8, 943.

[21] S. M. Glozman, V. S. Troitskaya, V. G. Vinokurov, V. A. Zagorevskii, Chem. Heterocycl. Compd., 1969, 5, 1, 19.

[22] S. M. Glozman, N. S. Tolmacheva, L. A. Zhmurenko, V. A. Zagorevskii, Pharm. Chem. J., 1973, 7, 2,68 .

[23] S. K. Panja, S. Maiti, M. G. B. Drew, C. Bandyopadhyay, Tetrahedron, 2009, 65, 7, 1276.

[24] N. A. Tyukavkina, G. A. Kalabin, V. V. Kononova, D. F. Kushnarev, Chem. Heterocycl. Compd., 1978, 14, 5, 497.

[25] F. A. Ragab, G. S. Hassan, H. A. Yossef, H. A. Hashem, Eur. J. Med. Chem., 2007, 42, 8, 1117.

[26] O. Abdelhafez, N. Abedelatif, F. Badria, Arch. Pharm. Res., 2011, 34, 10, 1623.

[27] P. D. Re, L. Verlicchi, I. V. O. Setnikar, J. Org. Chem., 1960, 25, 7, 1097.

[28] M. M. Garazd, Y. L. Garazd, A. S. Ogorodniichuk, V. V. Shilin, A. V. Turov, V. P. Khilya, Chem. Nat. Compd., 1998, 34, 4, 442.

[29] S. M. Glozman, P. A. Sharov, L. A. Zhmurenko, V. A. Zagorevskii, Pharm. Chem. J., 1974, 8, 6,337 .

[30] D. Wang, L. Hou, L. Wu, X. Yu, Chem. Pharm. Bull., 2012, 60, 4, 513.

[31] S. P. Bondarenko, M. S. Frasinyuk, V. P. Khilya, Chem. Nat. Compd., 2003, 39, 4, 344. 
[32] S. P. Bondarenko, M. S. Frasinyuk, V. P. Khilya, Chem. Nat. Compd., 2003, 39, 4, 340.

[33] M. S. Frasinyuk, S. P. Bondarenko, V. P. Khilya, Chem. Nat. Compd., 2006, 42, 2, 142.

[34] S. P. Bondarenko, M. S. Frasinyuk, V. I. Vinogradova, V. P. Khilya, Chem. Nat. Compd., 2011, 47, 4, 604 .

[35] S. P. Bondarenko, M. S. Frasinyuk, V. P. Khilya, Chem. Nat. Compd., 2003, 39, 3, 265.

[36] A. Aitmambetov, V. P. Khilya, Chem. Nat. Compd., 1994, 30, 5, 576.

[37] M. S. Frasinyuk, A. V. Turov, V. I. Vinogradova, V. P. Khilya, Chem. Nat. Compd., 2007, 43, $3,285$.

[38] V. P. Khilya, A. L. Kazakov, G. M. Golubushina, V. N. Mel'nik, T. M. Tkachuk, Pharm. Chem. J., 1981, 15, 11, 780.

[39] M. S. Frasinyuk, A. V. Turov, V. P. Khilya, Chem. Heterocycl. Compd., 1998, 34, 8, 923.

[40] M. S. Frasinyuk, N. V. Gorbulenko, V. P. Khilya, Chem. Heterocycl. Compd., 1997, 33, 9, 1078.

[41] N. V. Gorbulenko, S. A. Kirpa, V. P. Khilya, Chem. Heterocycl. Compd., 1993, 29, 1, 23.

[42] V. P. Khilya, I. P. Kupchevskaya, A. L. Kazakov, T. M. Tkachuk, G. M. Golubushina, Chem. Heterocycl. Compd., 1982, 18, 3, 240.

[43] N. V. Gorbulenko, M. S. Frasinyuk, V. P. Khilya, Chem. Heterocycl. Compd., 1994, 30, 4, 405.

[44] N. V. Gorbulenko, T. M. Tkachuk, T. V. Shokol, V. V. Semeniuchenko, A. V. Turov, V. P. Khilya, Chem. Heterocycl. Compd., 2007, 43, 5, 569.

[45] S. P. Bondarenko, M. S. Frasinyuk, Chem. Nat. Compd., 2013, 49, 5, 841.

[46] S. P. Bondarenko, A. V. Levenets, M. S. Frasinyuk, V. P. Khilya, Chem. Nat. Compd., 2003, 39, 3, 271.

[47] S. P. Bondarenko, M. S. Frasinyuk, V. P. Khilya, Chem. Nat. Compd., 2012, 48, 1, 26.
[48] T. B. Nguyen, O. Lozach, G. Surpateanu, Q. Wang, P. Retailleau, B. I. Iorga, L. Meijer, F. Guéritte, J. Med. Chem., 2012, 55, 6, 2811.

[49] F. Kxallay, G. JanzsX, Tetrahedron Lett., 1978, 19, 16, 1443.

[50] L. Chen, T.-S. Hu, J. Zhu, H. Wu, Z.-J. Yao, Synlett, 2006, 2006, 8, 1225.

[51] T. B. Nguyen, Q. Wang, F. Guéritte, Eur. J. Org. Chem., 2011, 2011, 35, 7076.

[52] R. Liu, B. Zhao, D.-E. Wang, T. Yao, L. Pang, Q. Tu, S. M. Ahmed, J.-J. Liu, J. Wang, Molecules, 2012, $17,12,14748$

[53] D. Joshi, J. Field, J. Murphy, M. Abdelrahim, H. Schönherr, J. R. Sparrow, G. Ellestad, K. Nakanishi, A. Zask, J. Nat. Prod., 2013, 76, 3, 450.

[54] N.-G. Li, S.-L. Song, M.-Z. Shen, Y.-P. Tang, Z.-H. Shi, H. Tang, Q.-P. Shi, Y.-F. Fu, J.-A. Duan, Bioorg. Med. Chem., 2012, 20, 24, 6919.

[55] T. Hari Babu, V. Rama Subba Rao, A. K. Tiwari, K. Suresh Babu, P. V. Srinivas, A. Z. Ali, J. Madhusudana Rao, Bioorg. Med. Chem. Lett., 2008, 18, 5, 1659.

[56] H. Gao, T. Nishioka, J. Kawabata, T. Kasai, Biosci., Biotech. Biochem., 2004, 68, 2, 369

[57] P. Yang, X. Kong, C. Cheng, C. Li, X. Yang, X. E. Zhao, Science China Chemistry, 2011, 54, 10, 1565.

[58] S. Zhang, J. Ma, Y. Bao, P. Yang, L. Zou, K. Li, X. Sun, Bioorg. Med. Chem., 2008, 16, 15, 7127.

[59] Y.-L. Mu, Y.-Y. Xie, L. Zhou, Y. Zhong, L. Liu, H. Bai, Y.-S. Wang, X.-M. Zhang, Chem. Biodiversity, 2009, 6, 8, 1170.

[60] S. P. Bondarenko, M. S. Frasinyuk, V. P. Khilya, Chem. Nat. Compd., 2009, 45, 4, 492.

[61] S. P. Bondarenko, M. S. Frasinyuk, V. P. Khilya, Chem. Heterocycl. Compd., 2010, 46, 2, 146.

[62] S. P. Bondarenko, M. S. Frasinyuk, A. I. Galaev, V. I. Vinogradova, Chem. Nat. Compd., 2012, 48, $2,234$. 
[63] M. M. Garazd, Y. L. Garazd, A. S. Ogorodniichuk, V. V. Shilin, A. M. Zhivolup, A. V. Turov, V. P. Khilya, Chem. Nat. Compd., 1998, 34, 5, 577

[64] M. S. Frasinyuk, S. P. Bondarenko, V. P. Khilya, C. Liu, D. S. Watt, V. M. Sviripa, Org. Biomol. Chem., 2015, 13, 4, 1053.

[65] P. da Re, L. Cimatoribus, Chem. Ber., 1962, 95, 12, 2912.

[66] L. Costantino, F. Gandolfi, C. Sorbi, S. Franchini, O. Prezzavento, F. Vittorio, G. Ronsisvalle, A. Leonardi, E. Poggesi, L. Brasili, J. Med. Chem., 2005, 48, $1,266$.

[67] H. R. Park, K.-S. Park, Y. Chong, Bioorg. Med. Chem. Lett., 2011, 21, 11, 3202.

[68] G. Mouysset, M. Payard, G. Grassy, P. Tronche, H. Dabire, P. Mouille, H. Schmitt, Eur. J. Med. Chem., 1987, 22, 6, 539.

[69] G. Baziard-Mouysset, S. Younes, Y. Labssita, M. Payard, D.-H. Caignard, M.-C. Rettori, P. Renard, B. Pfeiffer, B. Guardiola-Lemaitre, Eur. J. Med. Chem., 1998, $33,5,339$.

[70] S. Younes, Y. Labssita, G. Baziard-Mouysset, M. Payard, M.-C. Rettori, P. Renard, B. Pfeiffer, D.-H. Caignard, Eur. J. Med. Chem., 2000, 35, 1, 107.

[71] G. D. Hatnapure, A. P. Keche, A. H. Rodge, S. S. Birajdar, R. H. Tale, V. M. Kamble, Bioorg. Med. Chem. Lett., 2012, 22, 20, 6385.

[72] R. B. Gammill, J. Org. Chem., 1984, 49, 26, 5035

[73] R. B. Gammill, F. P. Bell, L. T. Bell, S. N. Bisaha, G. J. Wilson, J. Med. Chem., 1990, 33, 10, 2685.

[74] T. V. Shokol, N. V. Gorbulenko, A. V. Turov, V. P. Khilya, Chem. Heterocycl. Compd., 2012, 48, 8, 1181

[75] T. V. Shokol, N. V. Gorbulenko, A. V. Turov, V. P. Khilya, Chem. Heterocycl. Compd., 2013, 49, 2, 325.

[76] E. Winter, F. Lecerf-Schmidt, G. Gozzi, B. Peres, M. Lightbody, C. Gauthier, C. Ozvegy-Laczka, G. Szakacs, B. Sarkadi, T. B. Creczynski-Pasa, A.
Boumendjel, A. Di Pietro, J. Med. Chem., 2013, 56, 24, 9849.

[77] T. A. Geissman, J. Am. Chem. Soc., 1951, 73, $7,3355$.

[78] A. Cavalli, A. Bisi, C. Bertucci, C. Rosini, A. Paluszcak, S. Gobbi, E. Giorgio, A. Rampa, F. Belluti, L. Piazzi, P. Valenti, R. W. Hartmann, M. Recanatini, J. Med. Chem., 2005, 48, 23, 7282.

[79] S. Gobbi, A. Cavalli, A. Rampa, F. Belluti, L. Piazzi, A. Paluszcak, R. W. Hartmann, M. Recanatini, A. Bisi, J. Med. Chem., 2006, 49, 15, 4777.

[80] M. Recanatini, A. Bisi, A. Cavalli, F. Belluti, S. Gobbi, A. Rampa, P. Valenti, M. Palzer, A. Palusczak, R. W. Hartmann, J. Med. Chem., 2001, 44, 5, 672.

[81] V. V. Shynkar, A. S. Klymchenko, C. Kunzelmann, G. Duportail, C. D. Muller, A. P. Demchenko, J.-M. Freyssinet, Y. Mely, J. Am. Chem. Soc., 2007, 129, 7, 2187.

[82] S. M. Hasan, M. M. Alam, A. Husain, S. Khanna, M. Akhtar, M. S. Zaman, Eur. J. Med. Chem., 2009, 44, 12, 4896.

[83] X. D. Zhao, C. J. Sun, Q. Q. Yao, W. B. Li, Chin. Chem. Lett., 2010, 21, 5, 529.

[84] X.-B. Wang, W. Liu, L. Yang, Q.-L. Guo, L.Y. Kong, Med. Chem. Res., 2012, 21, 8, 1833.

[85] T. Akama, H. Ishida, U. Kimura, K. Gomi, H. Saito, J. Med. Chem., 1998, 41, 12, 2056.

[86] Y. Chen, M. Cheng, F.-Q. Liu, P. Xia, K. Qian, D. Yu, Y. Xia, Z.-Y. Yang, C.-H. Chen, S. L. MorrisNatschke, K.-H. Lee, Eur. J. Med. Chem., 2011, 46, 10, 4924.

[87] M. Carrara, F. Capolongo, L. Cima, G. Fabbri, A. Rampa, P. Valenti, P. Da Re, Coll. Czech. Chem. Commun., 1991, 56, 11, 2402

[88] P. Valenti, M. Recanatini, P. D. Re, L. Cima, P. Giusti, Arch. Pharm., 1983, 316, 5, 421.

[89] M. Recanatini, P. Valenti, P. D. Re, P. Giusti, Arch. Pharm., 1989, 322, 5, 257.

[90] P. Roveri, P. Valenti, P. da Re, Arch. Pharm., 1978, 311, 6, 465 . 
[91] G. P. Ellis, T. M. Romney-Alexander, J. Chem. Res., 1984, 11, 3101

[92] G. P. Ellis, I. L. Thomas, J. Chem. Soc., Perkin Trans. 1, 1974, 2570.

[93] Y.-P. Luo, G.-F. Yang, Bioorg. Med. Chem., 2007, 15, 4, 1716.

[94] C. Lee, J. M. Lee, N.-R. Lee, D.-E. Kim, Y.-J. Jeong, Y. Chong, Bioorg. Med. Chem. Lett., 2009, 19, 16, 4538 .

[95] C. Joo, E. Venkateswararao, K.-C. Lee, V. K. Sharma, M.-S. Kyung, Y. Kim, S.-H. Jung, Bioorg. Med. Chem., 2012, 20, 19, 5757.

[96] A. Kamal, E. Vijaya Bharathi, M. Janaki Ramaiah, J. Surendranadha Reddy, D. Dastagiri, A. Viswanath, F. Sultana, S. N. C. V. L. Pushpavalli, M. PalBhadra, A. Juvekar, S. Sen, S. Zingde, Bioorg. Med. Chem. Lett., 2010, 20, 11, 3310.

[97] G. R. Brown, A. M. Bamford, J. Bowyer, D. S. James, N. Rankine, E. Tang, V. Torr, E. J. Culbert, Bioorg. Med. Chem. Lett., 2000, 10, 6, 575.

[98] P. Thanigaimalai, K.-C. Lee, V. K. Sharma, J.H. Yun, Y. Kim, S.-H. Jung, Bioorg. Med. Chem., 2010, $18,13,4625$.

[99] K. Y. Lee, D. H. Nam, C. S. Moon, S. H. Seo, J. Y. Lee, Y. S. Lee, Eur. J. Med. Chem., 2006, 41, 8, 991.

[100] D. H. Nam, K. Y. Lee, C. S. Moon, Y. S. Lee, Eur. J. Med. Chem., 2010, 45, 9, 4288.

[101] B. Boduszek, M. Uher, Synth. Commun., 2000, 30, 10, 1749.

[102] D. Prajapati, M. Gohain, Synth. Commun., 2008, 38, 24, 4426.

[103] R. Abonia, B. Insuasty, J. Quiroga, H. Kolshorn, H. Meier, J. Heterocycl. Chem., 2001, 38, 3, 671.

[104] G. Savitha, P. T. Perumal, Tetrahedron Lett., 2006, 47, 21, 3589.

[105] S. A. R. Mulla, T. A. Salama, M. Y. Pathan, S. M. Inamdar, S. S. Chavan, Tetrahedron Lett., 2013, 54, 7, 672.
[106] A. G. P. R. Figueiredo, A. C. Tomé, A. M. S. Silva, J. A. S. Cavaleiro, Tetrahedron, 2007, 63, 4, 910.

[107] T. Ghosh, C. Bandyopadhyay, J. Chem. Res., 2007, 2007, 3, 190

[108] M. D. L. de la Torre, A. G. P. Rodrigues, A. C. Tomé, A. M. S. Silva, J. A. S. Cavaleiro, Tetrahedron, 2004, 60, 16, 3581 .

[109] S. Maiti, S. K. Panja, K. Sadhukhan, J. Ghosh, C. Bandyopadhyay, Tetrahedron Lett., 2012, 53, 6, 694.

[110] S. Maiti, T. M. Lakshmykanth, S. K. Panja, R. Mukhopadhyay, A. Datta, C. Bandyopadhyay, J. Heterocycl. Chem., 2011, 48, 4, 763.

[111] G. Singh, M. P. S. Ishar, V. Gupta, G. Singh, M. Kalyan, S. S. Bhella, Tetrahedron, 2007, 63, 22, 4773.

[112] N. K. Bejjanki, A. Venkatesham, J. Madda, N. Kommu, S. Pombala, C. Ganesh Kumar, K. R. Prasad, J. B. Nanubolu, Bioorg. Med. Chem. Lett., 2013, 23, 14, 4061 .

[113] K. Nagaiah, A. Venkatesham, R. Srinivasa Rao, V. Saddanapu, J. S. Yadav, S. J. Basha, A. V. S. Sarma, B. Sridhar, A. Addlagatta, Bioorg. Med. Chem. Lett., 2010, 20, 11, 3259.

[114] H. H. Abbas-Temirek, M. F. Aly, E. E. Elboray, Arkivoc, 2010, 2010, 3, 237

[115] M. P. S. Ishar, G. Singh, K. Kumar, R. Singh, Tetrahedron, 2000, 56, 39, 7817.

[116] G. Singh, A. Kaur, V. Sharma, N. Suri, P. R. Sharma, A. K. Saxena, M. P. S. Ishar, MedChemComm, 2013, 4, 6, 972.

[117] K. Wittstein, A. B. Garcia, M. Schuermann, K. Kumar, Synlett, 2012, 2012, 2, 227.

[118] D. Prajapati, S. P. Singh, A. R. Mahajan, J. S. Sandhu, Synthesis, 1993, 1993, 05, 468.

[119] E. A. A. Wallén, K. Dahlén, M. Grøtli, K. Luthman, Org. Lett., 2007, 9, 3, 389.

[120] S. V. Potnis, S. D. Samant, Indian J. Chem. B, 2002, 41, 4, 817

[121] R. N. Vydzhak, S. Y. Panchishyn, Russ. J. Gen. Chem., 2010, 80, 2, 323. 
[122] R. N. Vydzhak, S. Y. Panchishin, Russ. J. Gen.

Chem., 2006, 76, 10, 1681.

[123] R. N. Vydzhak, S. Y. Panchishin, Russ. J. Gen.

Chem., 2008, 78, 12, 2391.

[124] J. Schmutz, R. Hirt, F. Künzle, E. Eichenberger, H. Lauener, Helv. Chim. Acta, 1953, 36, 3, 620.

[125] T. Liu, Z. Xu, Q. He, Y. Chen, B. Yang, Y. Hu, Bioorg. Med. Chem. Lett., 2007, 17, 1, 278.

[126] G. Cordonnier, C. Randria, H. Sliwa, Tetrahedron Lett., 1994, 35, 46, 8617.

[127] H. Sliwa, C. Cordonnier, J. Heterocycl. Chem., 1977, 14, 1, 169. 